\title{
Penerapan Bimbingan Klasikal dengan Metode Brainstorming atau Curah Pendapat untuk Meningkatkan Pemahaman Konseli Generasi Z pada Topik Dampak Smartphone dan Media Sosial di Kelas XII MIPA.1 Semester 1 SMAN 4 Kota Bima Tahun Pelajaran 2020/2021
}

\author{
Sarifuddin* \\ SMAN 4 Kota Bima, Indonesia \\ *Coresponding Author: syarifuddinudin100@gmail.com \\ Dikirim: 04-11-2021; Direvisi: 05-11-2021; Diterima: 06-11-2021
}

\begin{abstract}
Abstrak: Penelitian tindakan kelas ini bertujuan untuk mendeskripsikan penerapan dan dampak penerapan bimbingan klasikal dengan metode brainstorming atau curah pendapat untuk meningkatkan pemahaman konseli generasi $\mathrm{Z}$ pada topik dampak smarpthone dan media sosial di kelas XII MIPA.1 semester I SMAN 4 Kota Bima tahun pelajaran 2020/2021. Konseli atau siswa yang peneliti bimbing adalah masuk dalam generasi Z, generasi native digital yang lahir tahun 1995-2010. Memahami tentang dampak smartphone dan media sosial dengan demikian sangat penting bagi generasi $\mathrm{Z}$ untuk membantu konseli memperoleh perkembangan yang normal, memiliki mental yang sehat. Subyek penelitian ini adalah siswa atau konseli kelas XII MIPA.1 SMAN 4 Kota semester I tahun pelajaran 2020/2021 sebanyak sebanyak 33 konseli, terdiri dari 15 laki-laki orang dan 18 di Bima. Hasil penelitian menunjukkan bahwa ketuntasan klasikan $70 \%$ pada pra siklus meningkat pada siklus I menjadi $80 \%$ dan 91, 50\% pada siklus II. Hasil tersebut membuktikan bahwa penerapan bimbingan klasikal dengan metode brainstorming atau curah pendapat dapat meningkatkan pemahaman konseli generasi $\mathrm{Z}$ pada topik dampak smarpthone dan media sosial di kelas XII MIPA.1 semester I SMAN 4 Kota Bima tahun pelajaran 2020/2021.
\end{abstract}

Kata Kunci: metode brainstorming; generasi Z; bimbingan klasikal

\begin{abstract}
This classroom action research aimed to describe the application and impact of applying classical guidance with the brainstorming or brainstorming method to improve the understanding of generation $\mathrm{Z}$ counselees on the topic of the impact of smartphones and social media in class XII MIPA.1 semester I SMAN 4 Kota Bima in the academic year 2020/2021. The counselees or students that the researchers guide were included in Generation Z, the digital native generation who were born in 1995-2010. Understanding about the impact of smartphones and social media was therefore very important for Generation $\mathrm{Z}$ to help counselees achieve normal development, have a healthy mentality. The subjects of this study were students or counselees of class XII MIPA.1 SMAN 4 Kota in the first semester of the 2020/2021 academic year as many as 33 counselees, consisting of 15 males and 18 females. The results showed that $70 \%$ classical completeness in the pre-cycle increased in the first cycle to $80 \%$ and $91,50 \%$ in the second cycle. These results prove that the application of classical guidance with the brainstorming or brainstorming method can improve the understanding of generation $\mathrm{Z}$ counselees on the topic of the impact of smartphones and social media in class XII MIPA.1 semester I SMAN 4 Kota Bima in the academic year 2020/2021.
\end{abstract}

Keywords: brainstorming method; Generation Z; classical guidance 


\section{PENDAHULUAN}

Digitalisasi dan bangkitnya generasi internet ini memberikan tantangan pada berbagai bidang. Perusahaan media massa misalnya, berjuang melakukan konvergensi media dan mengembangkan dirinya dengan platform digital untuk dapat beradaptasi dengan perkembangan internet dan generasi $\mathrm{Z}$ sebagai salah satu konsumennya. Kemudian masyarakat luas turut pula mengubah pola bermedia dari membaca koran menjadi membaca portal berita online melalui gawai pribadinya. Generasi $\mathrm{Z}$ diduga sebagai salah satu faktor yang menyebabkan matinya media cetak (Zuhra, 2017).

Generasi kini berkembang dalam kategori baby boomers, generasi X (tahun lahir antara 1961-1980), generasi Y (tahun lahir 1980-1995), dan generasi Z (19952010). Pengelompokkan ini adalah pengelompokan berdasarkan kesamaan rentang tahun lahir, lokasi, serta peristiwa-peristiwa yang memengaruhi secara signifikan kehidupan kelompok tersebut. Artinya generasi adalah kelompok individu yang mengalami peristiwa yang sama dalam kurun waktu yang sama (Putra, 2016: 125). Generasi yang menjadi sorotan tentu saja generasi yang muncul di akhir, paling tidak dalam kurun waktu sampai dengan 2019, yaitu generasi $\mathrm{Z}$ yang sering disebut sebagai igeneration atau generasi internet. Generasi internet bertumbuh dan berkembang seiring dengen digitalisasi di berbagai aspek. Mereka ahli dalam mengoperasikan berbagai media teknologi (digital natives) dan memiliki karakter unik multi-tasking yang membedakan dengan generasi sebelumnya.

Guru Bimbingan dan Konseling di era digital saat ini dihadapkan tantangan yang barangkali belum pernah dihadapi sebelumnya dalam menjalankan tugas. Tantangan dimaksud adalah dari segi konseli yang dibimbing dimana pada saat ini siwa yang dihadapi adalah konseli generasi $\mathrm{Z}$, generasi digital native yakni generasi yang mulai dari kecil, bahkan bayi sudah akrab dengan teknologi digital. Jika beberapa tahun yang lalu masih terdapat berbagai larangan bagi konseli untuk memanfaatkan smartphone, saat ini hal tersebut akan sulit diterapkan, terlebih pada saat pandemi Covid-19 dimana mau tidak mau konseli harus menggunakan smartphone dan media sosial seperti WA dan Facebook dan berbagai aplikasi seperti google form serta aplikasi lainnya yang dimanfaatkan untuk proses pembelajaran.

Penyelenggaraan BK dalam jalur formal (Depdiknas 2008) dan Permendikbud nomor 111 tahun 2014, dijelaskan bahwa komponen program bimbingan dan konseling meliputi layanan dasar, layanan peminatan dan perencanaan individual, layanan responsif, dan dukungan sistem. Selanjutnya di dalam Permendikbud tersebut, masing-masing komponen layanan dijelaskan sebagai berikut.

Layanan dasar bertujuan untuk membantu konseli memperoleh perkembangan yang normal, memiliki mental yan sehat, dan memperoleh keterampilan hidup. Secara rinci tujuan pelayanan dasar dirumuskan sebagai upaya untuk membantu konseli agar: (1) memiliki kesadaran (pemahaman) tentang diri dan lingkungannya (pendidikan, pekerjaan, sosial budaya dan agama), (2) mampu mengembangkan keterampilan untuk mengidentifikasi tanggung jawab atau seperangkat tingkah laku yang layak bagi penyesuaian diri dengan lingkungannya, (3) mampu memenuhi kebutuhan dirinya dan mampu mengatasi masalahnya sendiri, dan (4) mampu mengembangkan dirinya dalam rangka mencapai tujuan hidupnya.

Dengan demikian generasi $\mathrm{Z}$, yang lahir dan hidup di era digital perlu mendapatkan bimbingan pemahaman tentang dampak smartphone dan media sosial 
agar konseli memperoleh perkembangan yang normal, memiliki mental yang sehat, dan memperoleh keterampilan hidup sebagaimana terincikan menjadi 4 (empat) diatas.

Sebelum pelaksanaan penelitian, pada bimbingan pra siklus, peneliti telah melakukan secara bimbingan klasikal pemahaman dampak smartphone dan media sosial bagi konseli menggunakan metode ceramah dimana peneliti mendominasi kegiatan tersebut tanpa memberikan kesempatan yang luas kepada konseli untuk berkontribusi terhadap hal-hal yang berkaitan dengan dampak smartphone dan media sosial bagi konseli. Pada akhir kegiatan pembimbingan peneliti melakukan evaluasi. Evaluasi yang peneliti lakukan mengacu pada bimbingan dan konseling di jalur pendidikan formal (Depdiknas 2008), yang menjelaskan bahwa evaluasi atau penilaian merupakan segala upaya, tindakan atau proses untuk menentukan derajat kualitas kemajuan suatu kegiatan, yang berkaitan dengan pelaksanaan program bimbingan dan konseling. Penilaian mengacu pada kriteria tertentu sesuai dengan program bimbingan yang dilaksanakan. Hasil evaluasi pada pra siklus pemahaman dampak smartphone dan media sosial konseli adalah ketuntasan klasikal $75 \%$. Hal ini dibawah indikator kinerja yang peneliti tetapkan yakni ketuntasan minimal individual pemahaman konseli $\geq 85,00$ dan persentase pencapaian Kriteria Ketuntasan (indikator kinerja) secara klasikal adalah $\geq 90 \%$. Kinerja guru dalam melaksanakan Rencana Pelaksanaan Layanan (RPL) 75\% Rencana Pelaksanaan Layanan (RPL) yang disusun dapat terlaksana. Capaian ini dibawah indikator yang peneliti tetapkan yakni minimal $95 \%$.

Dari kajian referensi mutakhir dan diskusi dengan kolega guru BK peneliti menemukan metode yang diasumsikan tepat untuk meningkatkan pemahaman konseli generasi $\mathrm{Z}$ berkaitan dengan pemahanan kecerdasan emosi ini yakni metode brainstroming.

Menurut Roestiyah (2008:73) metode brainstorming yaitu teknik mengajar yang dilakukan guru dengan cara melontarkan suatu masalah ke kelas oleh guru, kemudian konseli menjawab, menyatakan pendapat, atau memberi komentar sehingga memungkinkan masalah tersebut berkembang menjadi masalah baru. Metode ini bertujuan untuk mengumpulkan gagasan atau pendapat dalam rangka menentukan dan memilih berbagai pernyataan sebagai jawaban terhadap pertanyaan yang berkaitan dengan layanan bimbingan. Maka, metode brainstorming ini dimanfaatkan peneliti dalam bimbingan klasikal untuk meningkatkan pemahaman konseli generasi $\mathrm{Z}$ topik dampak smartphone dan media sosial di kelas XII MIPA.1 semester I tahun pelajaran 2020/2021.

\section{KAJIAN TEORI}

\section{Metode Layanan Bimbingan Klasikal dan Bimbingan Kelompok}

Istilah metode layanan dapat disejajarkan dengan metode layanan bimbingan. Sebab dalam konteks bimbingan, aktivitas yang dilaksanakan konselor lebih menggunakan istilah layanan, yang pada hakekatnya juga merupakan proses membelajarkan konseli. Dengan demikian metode layanan bimbingan dapat diaplikasikan dalam layanan bimbingan. Uno dan Mohamad (2013) menjelaskan istilah metode dalam layanan bimbingan sebagai cara guru dalam menjalankan fungsinya dalam mencapai tujuan layanan bimbingan. Selanjutnya dijelaskan bahwa cara tersebut lebih bersifat prosedural, yaitu tahapan-tahapan yang ditempuh dalam 
layanan bimbingan, sesuai dengan metode yang digunakan. Konsep Uno tersebut jika diaplikasikan dalam bimbingan dapat dikatakan sebagai metode layanan, yaitu cara atau prosedur yang digunakan oleh konselor dalam rangka mencapai tujuan bimbingan.

Telah disebutkan di bagian sebelumnya bahwa dalam strategi bimbingan klasikal maupun strategi bimbingan kelompok, menggunakan pendekatan bimbingan kelompok. Di dalam bimbingan kelompok, menurut Gazda (dalam Romlah, 2006) dapat menggunakan metode instruktional dengan menerapkan konsep-konsep dinamika kelompok. Bagian berikut akan disajikan beberapa contoh metode bimbingan kelompok yang dikemukakan oleh Romlah (2006). Metode yang oleh Romlah disebut sebagai teknik bimbingan kelompok ini dapat digunakan dalam layanan bimbingan klasikal maupun bimbingan kelompok. Metode tersebut yaitu metode brainstorming.

\section{Metode Brainstorming}

Menurut Roestiyah (2008:73) metode brainstorming yaitu teknik mengajar yang dilakukan guru dengan cara melontarkan suatu masalah ke kelas oleh guru, kemudian konseli menjawab, menyatakan pendapat, atau memberi komentar sehingga memungkinkan masalah tersebut berkembang menjadi masalah baru. Secara singkat dapat diartikan sebagai satu cara untuk mendapatkan banyak/berbagai ide dari sekelompok manusia dalam waktu yang singkat. Sedangkan menurut Rawlinson (1977:27) brainstorming adalah cara untuk mendapatkan banyak ide dari sekelompok manusia dengan cara yang singkat. Dari dua pendapat tersebut dapat disimpulkan bahwa dengan metode brainstorming ini konseli dilatih untuk mencari, menemukan dan mengemukakan gagasannya sebanyak mungkin dalam proses layanan bimbingan.

Metode ini melatih keaktifan konseli dalam bertanya dan mengolah pertanyaan sehingga mendorong konseli untuk berpartisipasi dalam proses layanan bimbingan. Metode ini bertujuan untuk mengumpulkan gagasan atau pendapat dalam rangka menentukan dan memilih berbagai pernyataan sebagai jawaban terhadap pertanyaan yang berkaitan dengan layanan bimbingan. Dengan diterapkannya metode ini maka akan terjadi proses layanan bimbingan yang lebih aktif dengan gagasan-gagasan yang muncul dari para konseli.

Adapun langkah-langkah dari penerapan metode brainstorming ini menurut Rawlinson (1977:35) menjelaskan persoalan, guru mengangkat dan menjelaskan permasalahan yang diangkat kemudian menjelaskan cara konseli berpartisipasi dalam layanan bimbingan tersebut. Merumuskan kembali persoalan, guru menjelaskan kembali persoalan dan konseli merumuskan pertanyaan pertanyaan yang diajukan. Mengembangkan ide unik, maksudnya mengembangkan ide-ide yang inovatif dan diluar variasi kebiasaan yang mungkin bisa dikembangkan. Mengevaluasi ide yang dihasilkan, guru dan konseli mengevaluasi ide yang telah terkumpul dan menyimpulkannya.

\section{Pemahaman}

Menurut Kamus Besar Bahasa Indonesia, dari kata paham yang berarti mengerti benar (akan); tahu benar (akan); pandai dan mengerti benar (tentang suatu hal). Pemahaman selanjutnya diartikan proses, perbuatan memahami atau memahamkan (https://kbbi.kemdikbud.go.id). Menurut Benyamin S. Bloom 
pemahaman adalah kemampuan untuk menginterpretasi atau mengulang informasi dengan menggunakan bahasa sendiri. Menurut Poesprodjo, bahwa pemahaman bukan hanya kegiatan berpikir semata, melainkan pemindahan letak dari dalam disituasi yang lain. Pemahaman merupakan suatu kegiatan berpikir secara diamdiam dan menemukan dirinya dalam diri orang lain.

Pemahaman atau comprehension, adalah suatu kemampuan yang umumnya mendapat penekanan dalam proses belajar mengajar. Oleh karena itu, konseli dituntut untuk memahami atau mengerti apa yang diajarkan, mengetahui apa yang sedang dikomunikasikan dan dapat memanfaatkan isinya tanpa keharusan menghubungkan dengan hal-hal yang lain. Pemahaman mencakup kemampuan untuk menangkap makna dan arti dari bahan yang dipelajari. Pemahaman termasuk dalam salah satu bagian dari aspek kognitif, karena pemahaman merupakan tingkat berfikir yang lebih tinggi.

Mulyasa dalam Hartono (Hartono, 2008) menyimpulkan bahwa pemahaman konseli dalam proses layanan bimbingan dapat dikembangkan dengan memberi kepercayaan, komunikasi yang bebas dan pengarahan diri. Dalam hal ini, konseli akan lebih mudah untuk memahami pelajaran jika:

a. Dikembangkannya rasa percaya diri dalam diri konseli, sehingga konseli tersebut akan lebih mudah untuk memahami pelajaran yang diberikan.

b. Memberi kesempatan kepada konseli untuk berkomunikasi secara bebas dan terarah.

c. Melibatkan konseli secara aktif dan kreatif dalam proses layanan bimbingan secara keseluruhan sehingga pemahaman konseli terhadap layanan bimbingan dapat tercapai.

Berdasarkan pernyataan di atas, dapat disimpulkan bahwasanya pemahaman disini dapat diartikan sebagai kemampuan konseli untuk dapat memahami atau menguasai suatu bahan materi ajar dalam suatu layanan bimbingan. Pemahaman bukan hanya sekedar tahu, tetapi juga menginginkan konseli yang belajar dapat memanfaatkan atau mengaplikasikan apa yang telah dipahaminya. Apabila konseli tersebut memahami apa yang telah dipelajarinya, maka konseli tersebut akan siap untuk menjawab pertanyaan yang diberikan pada saat belajar.

\section{Assessmen}

\section{a. Konsep dasar asesmen dalam Bimbingan dan konseling}

Dalam buku yang Asesmen Bimbingan dan Konseling yang ditrbitkan Kementerian Pendidikan dan Kebudayaan Direktorat Jenderal Guru Dan Tenaga Kependidikan 2017 layanan ahli bimbingan dan konseling, mempersyaratkan bagi Guru BK atau konselor mengenali konseli secara mendalam baik pribadi maupun lingkungannya, dalam kerangka memetakan lintasan perkembangan kepribadian (developmental trajectory) konseli dari keadaannya sekarang ke arah yang dikehendaki. Selain itu Guru BK atau konselor selalu menggunakan penyikapan yang empatik, mengormati keragaman, serta mengedepankan kemaslahatan konseli dalam pelaksanaan layanan ahlinya, karena tiap individu/konseli menunjukkan adanya keberbedaan dalam banyak hal idiosinkratik, seperti: potensi diri dan lingkungan dalam wilayah bimbingan pribadi, sosial, belajar, dan karir.

Guru BK atau konselor dalam memahami karakteristik konseli menggunakan berbagai teknik non tes dalam rangka need assessment di tempat konseli belajar. Asesmen dalam rangka memahami diri konseli menggunakan dua teknik dasar yaitu 
teknik tes dan teknik non tes. Asesmen teknik tes adalah pengukuran psikologis dengan menggunakan alat tes yang terstandar, seperti: tes kecerdasan, tes bakat, tes minat, dan tes kepribadian. Asesmen teknik non tes adalah teknik asesmen yang tidak baku/terstandar dan sebagian besar merupakan hasil produk pengembangan Guru BK atau Guru BK atau konselor. Asesmen teknik non tes terdiri atas: (1) Other report observasi, (2) Self report wawancara, kuesioner, otobiografi, (3) Sosiometri, (4) Daftar Cek Masalah, dan (5) Catatan Kumulatif (Cummulative Records), yang terakhir lazim di sebut himpunan data.

\section{b. Teknik-Teknik Asesmen dalam Bimbingan dan konseling}

Asesmen lingkungan dan diri diperlukan dalam program bimbingan dan konseling komprehensif. Kebutuhan data lingkungan dan diri berisi sejumlah data yang lengkap mengenai diri dan lingkungan konseli yang direkam/diases dengan teknik asesmen diri yaitu teknik non tes dan teknik tes. Rekaman data yang lengkap tentang diri konseli mencakup: identitas diri, keluarga, riwayat kesehatan, riwayat pendidikan, kecerdasan, bakat, minat, kepribadian, pengalaman dan lingkungan sosial, harapan dan cita-cita, hobi dan kebiasaan, serta masalah-masalah dan kebutuhan. Teknik asesmen dalam bimbingan dan konseling terdiri atas teknik non tes dan tes. Dalam penelitian ini, asesmen pemahaman maka digunakan teknis tes karena yang tujuannnya untuk mengetahui pemahaman konseli tentang persahaan sejati.

\section{Smartphone dan Jejaring Medsos \\ a. Smartphone}

Menurut Baridwan (2010) Telepon cerdas (smartphone) adalah telepon genggam yang memiliki sistem operasi untuk masyarakat luas, fungsinya tidak hanya untuk SMS dan telepon saja tetapi pengguna dapat dengan bebas menambahkan aplikasi, menambah fungsi-fungsi atau mengubah sesuai keinginan pengguna. Dengan kata lain, telepon cerdas merupakan komputer mini yang mempunyai kapabilitas sebuah telepon.

Smartphone merupakan salah satu alat komunikasi yang sering dipakai saat ini, mulai dari kalangan anak-anak, remaja, dewasa, dan orang tua. Pada awalnya smartphone hanya untuk berkomunikasi saja, dengan seiring perkembangan zaman teknologi hingga bisa mengirim data dan menambah aplikasi yang disukai. Dewasa ini penggunaan media komunikasi merupakan kebutuhan pokok bagi individu, kelompok, maupun organisasi. Pada saat ini, peranan handphone sudah menjadi kebutuhan primer sehari-hari.

\section{b. Media sosial}

Menurut Hafied Cangara (2011) media adalah alat atau sarana yang digunakan untuk menyampaikan pesan dari komunikator kepada khalayak. Ada beberapa pakar psikologi memandang bahwa dalam komunikasi antarmanusia, media yang paling dominan dalam berkomunikasi adalah panca indra manusia, seperti mata dan telinga. Pesan-pesan yang diterima panca indra selanjutnya diproses dalam pikiran manusia untuk mengontrol dan menentukan sikapnya terhadap sesuatu, sebelum dinyatakan dalam tindakan.

Sedangkan definisi media sosial menurut Andreas Kaplan dan Michael Haenlein dalam Daniella Putri Islamy (2015) adalah sebuah kelompok aplikasi berbasis internet yang dibangun atas dasar ideologi dan teknologi Web 2.0, dan memungkinkan penciptaan serta pertukaran user-generated content. Web 2.0 menjadi 
platform dasar media sosial. Media sosial ada dalam berbagai macam bentuk, diantaranya termasuk social network, forum internet, weblogs, social blogs, micro blogging, wikis, podcasts, gambar, video, rating, dan boomark sosial. Menurut Kaplan dan Haenlein, ada enam jenis media sosial termasuk Instagram, yang masuk kategori jaringan sosial. Dalam konteks penelitian ini, WhatsApp yang lazim digunakan siswa atau konseli peneliti masukkan dalam kategori media sosial.

\section{METODE PENELITIAN}

Penelitian perbaikan layanan bimbingan ini diterapkan pada konseli kelas XII MIPA.1 semester I sebanyak 33 konseli, terdiri dari 15 laki-laki orang dan 18 orang perempuan di SMAN 4 Kota Bima tahun pelajaran 2020/2021. Perbaikan layanan dilaksanakan bimbingan klasikal dengan metode brainstorming atau curah pendapat untuk meningkatkan pemahaman konseli generasi $\mathrm{Z}$ pada topik dampak smarpthone dan media sosial.

Dari 33 konseli semuanya bertempat tinggal di Kota Bima dan Kabupaten Bima. Orang tua konseli sebagian besar bermata pencaharian sebagai PNS, petani, sebagian lain pegawai swasta, pedagang, dan lain-lain. Tingkat pendidikan orang tua mereka umumnya berijazah SMA dan yang sederajat.

Kegiatan perbaikan layanan bimbingan dilakukan melalui penelitian tindakan kelas. Penelitian dilaksanakan dengan mengacu prosedur penelitian tindakan kelas (PTK) atau Classroom Action Research (CAR). PTK dilaksanakan dalam bentuk perencanaan, tindakan, observasi dan refleksi yang merupakan langkah berurutan dalam satu siklus atau daur yang berhubungan dengan siklus berikutnya.

Dalam penelitian perbaikan layanan bimbingan ini penilaian terhadap pemahaman konseli dampak smarpthone dan media sosial dibatasi hanya pada ranah kognitif/pengetahuan dengan menggunakan tes tertulis untuk mengetahui tingkat kompetensi pengetahuan para konseli, selain itu juga dari LKS yang diisi oleh konseli selama proses diskusi berlangsung.

Kegiatan perbaikan layanan bimbingan dalam penelitian tindakan kelas ini dikatakan berhasil jika: 1) pemahaman konseli ditunjukkan oleh nilai asesment kelas XII MIPA. 1 semester I SMAN 4 Kota Bima mencapai $\geq 85,00$ dan persentase pencapaian Kriteria Ketuntasan Minimal secara klasikal adalah $\geq 90 \%$, dan 2) semua aspek kegiatan layanan yang ada dalam lembar observasi mencapai $\geq 95 \%$ atau kriteria "Sangat Baik".

\section{HASIL DAN PEMBAHASAN}

\section{Siklus 1}

Pada tahap perencanaan, peneliti dan kolaborator menyusun rangkaian tindakan yang akan dilaksanakan dalam bentuk RPL (Rencana Pelaksanaan Layanan). Selanjutnya, pelaksanaan tindakan dilakukan dalam kegiatan layanan bimbingan klasikal dengan metode brainstorming atau curah pendapat untuk meningkatkan pemahaman konseli generasi Z. Pada siklus 1, kegiatan inti ditandai dengan penayangan berita, video remaja yang kecanduan main game dan dampaknya, serta berita tentang perkelahian remaja disebabkan saling ejek di media sosial, serta berita hoax. Kemudian, dilanjutnkan dengan penayangan berita tentang remaja yang memenangkan berbagai lomba dengan bantuan media sosial, remaja 
yang berhasil meraih uang jutaan melalui kegiatan melakukan vlog atau lazimnya disebut nge-vlog akun media sosial you tube, siswa yang sedang berdikusi mengerjakan tugas menggunakan aplikasi pendidikan melalui Smartphone. Dengan penayangan video dan berita yang bertema sosial media dengan perspektif yang berbeda ini, guru membuka kesempatan kepada konseli atau siswa untuk memberikan pendapat terkait topik. Konseli mengemukakan pendapatnya, guru menginventarisir jawaban konseli, selanjutnya guru dan konseli menyimpulkan dampak smartphone dan media sosial, baik dampak positif maupun dampak negatif. Guru menyimpulkan pentingnya konseli cerdas dan bijak memanfaatkan smarpthone dan media sosial sehingga dapat menghidari atau meminimalisir dampak negatif smarpthone dan media sosial dan mengoptimalkan dampak positif smarpthone dan media sosial khususnya bagi konseli yang masuk dalam generasi $\mathrm{Z}$.

Pemahaman siswa terhadap topic dapat diamati pada Tabel1, dimana terlihat kenaikan pemahaman dibandingkan dengan pra siklus.

Tabel 1. Pemahaman Konseli

\begin{tabular}{ccc}
\hline & Pra Siklus & Siklus 1 \\
\hline Prosentase & $70 \%$ & $80 \%$ \\
\hline
\end{tabular}

Pada pengamatan kinerja guru pada siklus 1 dari berbagai aspek sehingga persentase kinerja guru meningkat $10 \%$ dari pra siklus, seperti yang ditunjukkan dalam Tabel 2.

Tabel 2. Kinerja Guru

\begin{tabular}{ccc}
\hline & Pra Siklus & Siklus 1 \\
\hline Prosentase & $85 \%$ & $90 \%$ \\
\hline
\end{tabular}

Hasil evaluasi dan asesmen yang dilakukan oleh peneliti dianalisa untuk disimpulkan dan ditindaklanjuti. Pada pemahaman konseli, ketuntasan prestasi belajar konseli masih berada di bawah standar yang ditetapkan ( $\geq 95 \%)$, yaitu $80 \%$. Demikian pula dari aspek kinerja guru sehingga persentase kinerja guru adalah $90 \%$ termasuk dalam kriteria "Baik", belum mencapai standar keberhasilan kinerja yang ditetapkan, yaitu $\geq 95 \%$ atau kriteria "Sangat Baik".

Berdasarkan kondisi dan permasalahan di atas maka perlu dilakukan perbaikan untuk tindakan berikutnya, yaitu:

a. Pada langkah ke-7 RTL, guru menayakan kepada konseli bagaimana pendapat siswa tentang dua jenis video dan berita tersebut?

Pada langkah ini, sebagian besar konseli, bingung tidak mengerti apa maksudnya guru, sehingga konseli tidak langsung memberikan respons. Terdapat siswa yang merespons dengan mengatakan bahwa apa yang ditayangkan di video dan berita tersebut benar, dan dia juga pernah melihat, membaca berita tersebut. Guru perlu memperjelas perintahnya sehingga siswa dipastikan mengerti apa yang harus dilakukan. Dalam hal ini untuk memberikan pendapat kepada konseli hubungannya dengan dampak, mana yang berdampak positif dan mana yang berdampak negatif.

b. Pada langkah ke-9 RTL, guru BK membagi kelas menjadi 6 kelompok, 1 kelompok terdiri 5 atau 6 orang. Selanjutnya guru membagikan video dan berita yang sudah ditayangkan. Guru memberi tugas kepada masing-masing kelompok untuk berdiskusi mengindentifikasi dampak smarpthone dan media sosial. 
Pada kegiatan ini terdapat 2 kelompok yang pasif yang lamban mengerjakan tugasnya karena sebagian besar anggota kelompoknya kemampuan sedang dan rendah. Sebaliknya terdapat 3 kelompok yang mengerjakan tugas lebih cepat dari waktu yang disediakan karena anggota kelompoknya pintar-pintar. Pada langkah ini guru perlu mengatur pembagian kelompok lebih proporsional, sehingga tidak terdapat kelompok yang mendominasi kegiatan pembelajaran. Demikian juga batasan waktu untuk mengerjakan tugas harus disesaikan dengan tugas yang diberikan, serta guru perlu memonitor kegiatan dan memastikan seluruh kelompok mengerjakan tugas dan dapat menyelesaikan tugas sesuai waktu yang ditentukan.

Oleh karena itu, perbaikan pada siklus 1 belum berhasil dan perlu diadakan tindakan perbaikan untuk siklus 2 .

\section{Siklus 2}

Pada tahap perencanaan siklus 2, peneliti menyusun rangkaian tindakan yang akan diterapkan pada siklus 2 yang merupakan hasil refleksi dan penyempurnaan dari tindakan pada siklus 1 . Kegiatan yang dilakukan pada tahap perencanaan adalah menyusun rangkaian tindakan yang akan dilaksanakan berdasarkan refleksi kegiatan layanan bimbingan pada siklus 1. Peneliti mendiskusikan isi rencana layanan bimbingan dengan kolaborator. Bersama kolaborator, kemudian disusun skenario rencana perbaikan layanan (RPL Perbaikan) pada siklus 2.

Langkah-langkah pembelajaran masih relatif sama dengan pelaksanaan pada siklus 1 dengan beberapa modifikasi dan perubahan yang merupakan hasil refleksi dari siklus 1, terutama bagian-bagian RTL yang menemui kekurangan sesuai hasil refleksi. Pelaksanaan tindakan perbaikan dilakukan dengan mengikuti RTL modifikasi untuk siklus 2. Maka, hasil tes pemahaman dan pengamatan siklus 2 dapat dilihat dalam Tabel 3.

Tabel 3. Pemahaman Konseli

\begin{tabular}{cccc}
\hline & Pra Siklus & Siklus 1 & Siklus 2 \\
\hline Prosentase & $70 \%$ & $80 \%$ & $91.50 \%$ \\
\hline
\end{tabular}

Hasil pengamatan kinerja guru untuk siklus 2 dapat diamati pada Tabel 4, dimana hasilnya menunjukkan hasil yang meningkat dari pra siklus dan siklus 1 .

Tabel 4. Kinerja Guru

\begin{tabular}{cccc}
\hline & Pra Siklus & Siklus 1 & Siklus 2 \\
\hline Prosentase & $85 \%$ & $90 \%$ & $96.80 \%$ \\
\hline
\end{tabular}

Hasil asesmmen pemahaman konseli bisa dilihat bahwa pada siklus 2 terjadi peningkatan yang signifkan, diperoleh ketuntasan klasikal sebesar 91,50\%. Pada pengamatan kinerja guru siklus 2 dari berbagai aspek pengamatan, persentase kinerja guru adalah 96,80\% termasuk dalam kriteria "Sangat Baik" dan telah mencapai standar keberhasilan kinerja yang ditetapkan, yaitu $\geq 95 \%$ dengan kriteria "Sangat Baik".

Rekomendasi yang diperoleh dari siklus 1 yang memuat kekurangan dan kelebihan serta cara memperbaikinya, dapat dilaksanakan dengan baik pada siklus 2 . Penguasaan pemahaman konseli meningkat secara signifikan. Berdasarkan hasil asesmen, ketuntasan individual maupun persentase ketuntasan klasikal sudah 
mencapai indikator keberhasilan yang diharapkan. Oleh karena itu, peneliti menyimpulkan bahwa layanan bimbingan yang dilaksanakan sudah optimal sehingga tidak diteruskan pada siklus selanjutnya.

Penerapan bimbingan klasikal dengan metode brainstorming atau curah pendapat dapat yang merupakan upaya menciptakan suasana yang menyenangkan. Dalam suasana yang demikian ini, diharapkan konseli dapat lebih terbuka dalam mengungkapkan diri termasuk mengungkapkan masalah-masalah yang dihadapinya serta ide-ide cemerangnya berkaitan dengan masalah yang dihadapi sehari-hari siswa baik di rumah, di sekolah maupun di masyarakat, sehingga konseli lebih bijak dalam menggunakan Smartphone karena lebih memahami dampaknya, baik dampak posisif mauun dapak negatif. Sampai pada siklus 2 dapat terlaksana dengan optimal sehingga meningkatkan pemahaman konseli generasi $\mathrm{Z}$ pada topik dampak smarpthone dan media sosial di kelas XII MIPA.1 semester I SMAN 4 Kota Bima tahun pelajaran 2020/2021.

\section{KESIMPULAN}

Hasil penelitian tindakan perbaikan dengan menerapkan bimbingan klasikal dengan metode brainstorming atau curah pendapat menunjukkan peningkatan pemahaman konseli generasi $\mathrm{Z}$ dan juga peningkatan kinerja guru BK secara signifikan pada topik dampak smarpthone dan media sosial di kelas XII MIPA.1 semester I SMAN 4 Kota Bima tahun pelajaran 2020/2021.

\section{DAFTAR PUSTAKA}

Bloom, Benyamin S. (1979). Taxonomy of Educational Objective. New York: Longman.

Djaali. (2011). Psikologi Pendidikan. Jakarta: Bumi Aksara

Daniella Putri Islamy. (2015). Pengaruh Online Shop Pada Media sosial Instagram Terhadap Perilaku Konsumtif Siswa-Siswi SMP Islam Cikal Harapan Bumi Serpong Damai (BSD) Kota Tangerang Selatan, Skripsi, Program Studi Komunikasi dan Penyiaran Islam, Fakultas Dakwah dan Ilmu Komunikasi UIN Syarif Hidayatullah. Jakarta: UIN Syarif Hidayatullah

Departemen Pendidikan dan Kebudayaan. (2008). Penataan Pendidikan Profesional Konselor dan Layanan Bimbingan dan Konseling dalam Jalur Pendidikan Formal. Diperbanyak oleh Jurusan PPB FIP UPI untuk lingkungan terbatas.

Depdiknas. (2003). Undang-undang RI No.20 tahun 2003 tentang sistem pendidikan nasional.

Hafied Cangara. (2011). Pengantar Ilmu Komunikasi. Jakarta: Raja Grafindo Persada

Hartono dkk, PAIKEM (Layanan bimbingan Aktif Inovatif Kreatif Efektif dan Menyenangkan), (Pekanbaru: Zanafa Publishing, 2008), hal.1

Istilah bimbingan oleh Romlah (2006) Romlah, T. 2006. Teori dan Praktik Bimbingan Kelompok. Malang: Penerbit Universitas Negeri Malang. 
M. Ramli Nur, (2017). asesmen bimbingan dan konseling

Mendikbud. (2014). Permendikbud nomor 111 tentang bimbingan dan konseling pada pendidikan dasar dan pendidikan menengah. Jakarta: MenteriPendidikan Nasional.

Putra, Yanuar Surya. (2016). "Theoritical Review : Teori Perbedaan Generasi”. Jurnal Among Makarti. 9(18), 124-134.

Uno, Hamzah B dan Nurdin Mohamad. (2013). Belajar dengan Pendekatan PAIKEM: Layanan bimbingan Aktif, Inovatif, Lingkungan, Kreatif, Efektif, Menarik. Jakarta: PT Bumi Aksara.

Zaki Baridwan. (2010). Intermediate Accounting. Yogyakarta: Universitas Gajah Mada

Zuhra, Wan Ulfa Nur (2017). "Kelahiran Generasi Z, Matinya Media Cetak" dalam https://tirto.id/kelahiran-generasi-z-kematian-media-cetak-ctLa diakses pada 3 November 2021 pukul 11:11 WITA. (https://kbbi.kemdikbud.go.id). 